\title{
Induction of Salt Tolerance in Tomato Through Seed Priming
}

\author{
Samar Biswas, Md. Rasal-Monir, Mohaiminul Islam, Sourav Modak, \\ Mohammad Humayun Kabir*
}

Department of Horticulture, Sher-e-bangla Agricultural University, Dhaka, Bangladesh

Email address:

kabirsau@yahoo.com (M. H. Kabir)

${ }^{*}$ Corresponding author

\section{To cite this article:}

Samar Biswas, Md. Rasal-Monir, Mohaiminul Islam, Sourav Modak, Mohammad Humayun Kabir. Induction of Salt Tolerance in Tomato Through Seed Priming. Plant. Vol. 7, No. 3, 2019, pp. 47-53. doi: 10.11648/j.plant.20190703.14

Received: August 11, 2019; Accepted: August 22, 2019; Published: September 5, 2019

\begin{abstract}
A pot experiment was conducted in the Net House of "Field Laboratory of Plant Stress Management" in the Horticulture farm of Sher-e-Bangla Agricultural University, Dhaka, during the period from October 2016 to March 2017. The two factors experiment was laid out in Complete Randomized Design with five replications. Factor A is three tomato varieties viz. $\mathrm{V}_{1}=$ Exotic line 1 (Korean), $\mathrm{V}_{2}=$ Exotic line 2 (Taiwan) and $\mathrm{V}_{3}=$ BARI tomato 14 and factor $\mathrm{B}$ is seed priming treatment viz. $\mathrm{P}_{0}=$ No priming (Control), $\mathrm{P}_{1}=$ Hydropriming (distilled water), $\mathrm{P}_{2}=\mathrm{NaCl}$ priming $(50 \mathrm{mM})$ and $\mathrm{P}_{3}=\mathrm{KNO}_{3}$ priming $(200$ $\mathrm{mM})$. The total treatment combinations were $(4 \times 3) 12$ and $8 \mathrm{dS} / \mathrm{m}$ fixed salinity maintained for all the pots. The experimental results exhibited that seed priming treatment significantly affected growth, yield and quality parameters of tomato. The highest plant height $(137.10 \mathrm{~cm})$, number of fruits per plant (40.92) and fruit yield per plant $(585.00 \mathrm{~g})$ were found from $\mathrm{V}_{1}$ under 8 $\mathrm{dS} / \mathrm{m}$ salinity level. In case of seed priming, the highest plant height $(150.10 \mathrm{~cm})$, number of fruits per plant $(48.11)$ and fruit yield per plant $(755.80 \mathrm{~g})$ were recorded from $\mathrm{P}_{2}$ mostly at $8 \mathrm{dS} / \mathrm{m}$ salinity level. Regarding the combined effect, the highest plant height $(187.00 \mathrm{~cm})$, number of fruits per plant $(55.00)$ and fruit yield per plant $(829.30 \mathrm{~g})$ were found from $\mathrm{V}_{1} \mathrm{P}_{2}$ under 8 $\mathrm{dS} / \mathrm{m}$ salinity level. So, Exotic line 1 with $\mathrm{NaCl}$ priming $(50 \mathrm{mM})$ showed better performance for growth, yield and quality of tomato under saline condition.
\end{abstract}

Keywords: Tomato, Stress, Seed Priming, Salt Tolerance

\section{Introduction}

Tomato (Lycopersicon esculentum Mill.) is important amongst the most substantial vegetables and broadly cultivated in Bangladesh. It is the second biggest vegetable cultivated after potato in Bangladesh. It is considered as a significant "defensive nourishment" as a result of its exceptional nutritive value. The whole area under tomato production in Bangladesh is around 68, 366 acres of land with a yield of $3,88,725$ tons and a productivity of 5.69 tons/acres of land [1]. In Bangladesh, it is commonly termed as "poor man's apple" and widely grown throughout the country. It is mainly cultivated as Rabi crop in Bangladesh.

The coastal area covers about $20 \%$ of the country and over thirty percent of the net cultivable area. It extends inside up to $150 \mathrm{~km}$ from the coast. Out of 2.85 million hectares of the coastal and offshore areas about 0.83 million hectares are arable lands, which cover over $30 \%$ of the total cultivable lands of Bangladesh. [2].

During the lifecycle, tomato crop come across a number of biotic and abiotic stresses which severely limit the production. Among the abiotic stresses, salinity, drought, temperature, mineral toxicity, U. V radiations are vital for yield constraints. Abiotic factors are considered to be the main cause of yield reduction up to $71 \%$ [3]. Salinity is one of the major abiotic stresses which adversely affect the crop yield. It is known to exercise depressive effects on metabolic pathway and energy generating processes in seeds under saline conditions.

Tomatoes, one of the most important and widespread crops 
in the world, are classified as moderately salt tolerant [4]. But high concentration of salt causes hyper osmotic and ionic stresses which in turn generate secondary stresses such as oxidative stress, ionic imbalance and ultimately cell death. [5].

Pretreatment of seed has been used not only to increase salt tolerance during germination and early growth stages [6] but also can have effects during fruiting. Plants from tomato seeds primed in $1 \mathrm{M} \mathrm{NaCl}$ for $36 \mathrm{~h}$ produced a greater fruit yield at low $(35 \mathrm{mM} \mathrm{NaCl})$ and moderate $(70 \mathrm{mM} \mathrm{NaCl})$ salt levels in the irrigation water than non-primed seed [7]. The positive effect of seed priming on yield was not clear at 140 $\mathrm{mM}$ since the negative effect of high salinity during the growing period dominates the positive effect of seed-priming [7]. This adaptation could be due to the sum of the adaptation induced by priming the seed with salt, plus adaptation induced by salinity during radicle emergence, as fruit yield also increased in plants primed at germination [8]. The faster growth of tomato plants from primed seeds seems to be the result of a higher capacity for osmotic adjustment because plants from primed seeds have more $\mathrm{Na}+$ and $\mathrm{Cl}_{-}$in roots and more organic acids and sugars in leaves than plants from non-primed seeds [9].

A large number of studies confirmed that various seed pretreatments triggering the so-called "pre-germinative metabolism" [10] have been used to improve seeds germination [11, 12], seedling establishment and increase plant vigor and yield [12].

The advantage of seed priming in reducing the germination time and improving emergence uniformity is well established under laboratory conditions. However, a very few detailed studies have been conducted on performance of primed seeds under field conditions. Earlier works showed that the success of seed priming is influenced by the complex Combined of factors including plant species, water potentiality of the priming agent, duration of priming, temperature, seed vigour and storage conditions of primed seeds [13]. Limited attempts are made to compare the crop specific efficacy of all the popular methods of priming viz., hydro priming (soaking in water), halo priming (soaking in inorganic salt solutions), osmo priming (soaking in solutions of different organic osmotica), thermo priming (treatment of seed with low or high temperatures), solid matrici priming (treatment of seed with solid matrices) and biopriming (hydration using biological compounds) on seedling vigour and plant performance. Since, seed priming is found to be a useful technology there is a need to standardize this technology in every crop species particularly in vegetables and floriculture crops. Being low cost and simple technique, this on-farm seed priming represents good insurance for risk-averse to resource poor farmers and can be promoted as low cost, low risk technology that would be appropriate for all farmers irrespective of their socio-economic status. Hence, the present study was taken up to induce salinity tolerant in tomato through seed priming, determine the effect of seed priming on the growth, yield and quality of tomato. And find out the suitable combination of seed priming and variety for ensuring the higher yield of tomato under saline condition.

\section{Materials and Methods}

\subsection{Experimental Design}

The soil salinity level was fixed to $8 \mathrm{ds} / \mathrm{m}$ for all the pots. The experiment was set up in a two factor completely randomized design with five replications. Thus 60 experimental pots were placed in ambient air at the net house premises of "Field Laboratory of Plant Stress Management lab." The salinity in irrigation water was developed by adding required amounts of $\mathrm{NaCl}$ salt in irrigation water as per the procedure of Michael [14] and Ponnamperuma [15].

\subsection{Seed Priming Procedure}

A quantity of $3 \mathrm{~g}$ seeds from each tomato variety was superficially sterilized with sodium hypochlorite solution (1\%) for 3 minutes and then thoroughly washed for 5 minutes with distilled water. After that, seeds of each varieties were primed with 200 millimoles $(\mathrm{mM})$ of $\mathrm{KNO}_{3}$ solution for $8 \mathrm{hrs}$. [16].) and For $\mathrm{NaCl}$ priming, seeds of each varieties were primed with $50 \mathrm{mM}$ of $\mathrm{NaCl}$ solution for $24 \mathrm{~h}$. For hydropriming, seeds were soaked in distilled water for the same duration [17]. Few seeds were untreated and seed priming was done in Horticulture and Biotechnological Lab, M. A. Wajed Miah Research Laboratory, SAU.

$20.22 \mathrm{~g}$ of $\mathrm{KNO}_{3}$ was dissolved in $1000 \mathrm{ml}$ of distilled water and $2.93 \mathrm{~g}$ of $\mathrm{NaCl}$ was dissolved in $1000 \mathrm{ml}$ of distilled water.

\subsection{Imposition of Salinity Treatments}

First application of salt water in the soil was applied 30 days after seedling transplanting. After that two application of salt water was applied in 15 days interval. The developed irrigation water salinity and pot soil were measured by using an electrical conductivity meter (HANNA HI 993310, Direct Salinity Meter). which was expressed in $\mathrm{dS} / \mathrm{m}$.

\subsection{Preparation and Application of Salt Solution}

Saline water was synthesized by using Emplura Sodium Chloride. $4.68 \mathrm{~g}$ of salt was dissolved in 1-liter tap water to prepare the salt solution. The salinity level of the salt solution was $8 \mathrm{dS} / \mathrm{m}$. Saline water was applied to the plant as irrigation. $500 \mathrm{ml}$ of well-prepared saline water was applied to every pot.

\subsection{SPAD Value}

Leaf chlorophyll content as SPAD values were measured from the youngest fully-expanded leaf in the third position from the tip by a portable chlorophyll meter (SPAD-502, Konica Minolta, Japan). The SPAD-502 chlorophyll meter can estimate total chlorophyll amounts in the leaves of a variety of species with a high degree of accuracy and is a 
nondestructive method [18]. SPAD was recorded at flowering stage and 30 days after flowering.

\subsection{Measurement of Vitamin-C}

Oxidation Reduction Titration method was used for determination of vitamin-c in ripen tomato juice. Extract of tomato fruit juice was used for determination of Vitamin-C content in per $100 \mathrm{~g}$ of tomato sample. It has expressed as $\mathrm{mg}$ Vitamin-C per $100 \mathrm{gm}$ of tomato. Tomato juice was prepared by blender and the volume was made with meta phosphoric acid up to $100 \mathrm{ml} .5 \mathrm{ml}$ of standard L-ascorbic solution was taken in a conical flask. Then it was titrated with 2,6 dichlorophenol indophenol taken in a burette. The end point was reached when the pink color lasts 10 seconds. Similarly, $5 \mathrm{ml}$ of tomato juice was titrated with dye. It was measured in "Biotechnological and Horticultural Stress Management Lab,” M. A. Wajed Miah Research Centre, SAU.

Calculation:

Vitamin-C content or L-ascorbic acid content $=\frac{0.5 \times \text { mean value of unknown solution reading } \times 100}{\text { Mean value of Known solution reading } \times 5} \mathrm{mg}$ of $\mathrm{L}$-ascorbic acid

\subsection{Determination of Proline and Carotenoid Content}

For proline determination, $0.1 \mathrm{~g}$ of leaf sample was collected from each tomato variety which was developed from different seed priming treatment and chopped into small pieces. The chopped sample was then transferred to a test tube containing $15 \mathrm{~mL}$ of $80 \%$ ethanol. The test tubes were incubated in $60^{\circ} \mathrm{C}$ water bath for 30 minutes (Troll and Lindley 1955). The incubated sample was filtered using Whatman No. 1 filter paper. $2 \mathrm{~mL}$ of filtered extract was added to a test tube containing $2 \mathrm{~mL}$ of ninhydrin acid and 2 $\mathrm{mL}$ of glacial acetic acid. The test tubes were incubated in $100^{\circ} \mathrm{C}$ water bath for 1 hour. Incubated test tubes were placed in cold water for termination of reaction. $4 \mathrm{~mL}$ of toluene was added into each test tube and vortexed vigorously to form two distinct layers. The aqueous layer was used for proline determination and absorbance reading was recorded

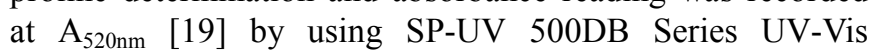
Spectrophotometer and data were computed based on the proline standard curve.

For determination of carotenoid, $0.1 \mathrm{~g}$ of ripen fruit sample was collected from each tomato variety and ground with $1 \mathrm{~g}$ of Calcium Carbonate $\left(\mathrm{CaCO}_{3}\right)$. Total of $25 \mathrm{~mL}$ of $80 \%$ acetone was added to the power and mixed evenly. The mixture was filtered by Whatman No. 1 filter paper and filtrate was collected to determine carotenoid [20]. The absorbance was measured at $440 \mathrm{~nm}$ by using SP-UV 500DB Series UV-Vis Spectrophotometer to determine carotenoid content and calculated by using following this equation:

$$
\text { Carotenoid Content }(\mu \mathrm{g} / \mathrm{g})=\frac{A \times V(m L) \times 10^{4}}{A_{1 \mathrm{~cm}}^{1 \%} \times P(g)}
$$

\subsection{Measurement of Total Soluble Solids (TSS)}

Refract meter (Model RHB 32 ATC) was used to measure TSS. One tomato sample was collected from each of the treatment. Tomato samples were cut with the sharp knife and inside was squeeze with the needle for sample juice. A drop of tomato fruit juice was placed on the transparent glass and it was covered by the upper glass. Brix refract meter was directly showed the TSS as percentage.

\subsection{Analysis of Data}

The data in respect of growth, yield contributing characters and growth \& fruit quality parameters were statistically analyzed to find out the statistical significance of the experimental results. The analyses were done following the software SPSS. The significance of the difference among the means was evaluated by the Least Significant Difference Test (LSD) at 5\% level of probability.

\section{Result and Discussion}

The experimental results obtained in this study are presented and discussed under following heads.

\subsection{Plant Height}

The data on plant height of tomato plant as influenced by different seed priming treatments was presented in the Table 1 . Significant variation in the plant height was noticed at 90 DAT among different varieties and seed priming treatments under saline condition. As influenced by different priming treatments a mean plant height $(\mathrm{cm})$ has shown in the (Table 1.) at 90 DAT. It was highest $(150.10 \mathrm{~cm})$ from $\mathrm{NaCl}$ seed priming $(50 \mathrm{mM})$ treatment and lowest plant height $(82.44 \mathrm{~cm})$ was recorded from control under saline condition (Table 1).

Significant variation was observed by the varietal effect on plant height of tomato (Table 2). Exotic line 1 (Korean) tomato plant showed highest plant height $(137.10 \mathrm{~cm})$ due to seed priming under saline condition. Lowest plant height $(98.75 \mathrm{~cm})$ was recorded in BARI tomato 14 (Table 2).

The Combined effect of seed priming and varieties showed significant variation on plant height. The experiment findings noticed the variation among all the treatments (Table 3 ). The highest plant height $(187.00 \mathrm{~cm})$ was recorded from $\mathrm{V}_{1} \mathrm{P}_{2}$ where the lowest plant height $(73.67 \mathrm{~cm})$ was achieved from $\mathrm{V}_{3} \mathrm{P}_{0}$ which was statistically similar with $\mathrm{V}_{2} \mathrm{P}_{3}, \mathrm{~V}_{2} \mathrm{P}_{0}$ and $\mathrm{V}_{1} \mathrm{P}_{0}$.

The increased plant height influenced by seed priming in the present study might be due to rapid cell division in meristematic region, number of cells and increase in cell elongation due to multiplication of various parts of the plant tissue, auxin metabolism, cell wall plasticity and permeability of cell membrane, increasing photosynthates [21]. A progressively increased enhancement with osmo-priming [22]. 
Table 1. Effect of priming treatments on yield contributing parameters of tomato under saline condition.

\begin{tabular}{lllllll}
\hline Treatments & Plant height (cm) & $\begin{array}{l}\text { Number of branches } \\
\text { per plant }\end{array}$ & Leaf area $\left.\mathbf{( c m}^{2}\right)$ & $\begin{array}{l}\text { Number of flower } \\
\text { cluster per plant }\end{array}$ & $\begin{array}{l}\text { Number of fruits } \\
\text { per plant }\end{array}$ & $\begin{array}{l}\text { Fruit yield per } \\
\text { plant }(\mathbf{g})\end{array}$ \\
\hline $\mathrm{P}_{0}$ & $82.44 \mathrm{c}$ & $8.67 \mathrm{c}$ & $158.40 \mathrm{~d}$ & $9.78 \mathrm{c}$ & $22.22 \mathrm{c}$ & $373.10 \mathrm{~d}$ \\
$\mathrm{P}_{1}$ & $119.40 \mathrm{~b}$ & $13.67 \mathrm{~b}$ & $221.00 \mathrm{c}$ & $15.11 \mathrm{~b}$ & $34.44 \mathrm{~b}$ & $478.00 \mathrm{c}$ \\
$\mathrm{P}_{2}$ & $150.10 \mathrm{a}$ & $18.56 \mathrm{a}$ & $332.60 \mathrm{a}$ & $20.44 \mathrm{a}$ & $48.11 \mathrm{a}$ & $755.80 \mathrm{a}$ \\
$\mathrm{P}_{3}$ & $118.10 \mathrm{~b}$ & $15.00 \mathrm{~b}$ & $258.10 \mathrm{~b}$ & $16.56 \mathrm{~b}$ & $34.00 \mathrm{~b}$ & $562.10 \mathrm{~b}$ \\
$\mathrm{CV} \%$ & 6.83 & 17.79 & 7.68 & 13.10 & 17.09 & 18.88 \\
\hline
\end{tabular}

In a column means similar letter (s) are statistically similar and those having dissimilar letter (s) differ significantly.

\subsection{Number of Branches Per Plant}

Number of branches per plant of tomato was significantly affected by the different seed priming treatment under saline condition at 90 DAT (Table 1). At 90 DAT, where the highest Number of branches per plant (18.56) was found from $\mathrm{P}_{2}$ and the lowest value (8.67) was found from $\mathrm{P}_{0}$.

A significant effect of varieties under salinity stress was found on the number of branches per plant of tomato at 90 DAT (Table 2). At 90 DAT, the highest number of branches per plant (17.17) was observed from $\mathrm{V}_{1}$ and the lowest value (10.58)) was found from $\mathrm{V}_{3}$.
The Combined effect of seed priming and variety on number of branches per plant of tomato exhibited a significant effect at 90 DAT (Table 3). At 90 DAT, the highest number of branches per plant (22.00) was found from $\mathrm{V}_{1} \mathrm{P}_{2}$ which was statistically similar with $\mathrm{V}_{1} \mathrm{P}_{3}$ (19.33) $\mathrm{V}_{3} \mathrm{P}_{3}$ (18.67) and $\mathrm{V}_{3} \mathrm{P}_{1}$ (16.67). The lowest value (6.67) was found from $\mathrm{V}_{3} \mathrm{P}_{0}$ which was statistically similar with $\mathrm{V}_{2} \mathrm{P}_{0}(8.00)$ and $\mathrm{V}_{2} \mathrm{P}_{1}$ (10.00). The positive influence of seed priming in improving the productive branches and there by increased yield.

Table 2. Effect of different varieties on yield contributing parameters of tomato under saline condition.

\begin{tabular}{lllllll}
\hline Treatments & Plant height $\mathbf{( c m )}$ & $\begin{array}{l}\text { Number of branches } \\
\text { per plant }\end{array}$ & $\begin{array}{l}\text { Leaf area } \\
\left.\mathbf{( c m}^{2}\right)\end{array}$ & $\begin{array}{l}\text { Number of flower cluster } \\
\text { per plant }\end{array}$ & $\begin{array}{l}\text { Number of fruits per } \\
\text { plant }\end{array}$ & $\begin{array}{l}\text { Fruit yield per } \\
\text { plant }(\mathbf{g})\end{array}$ \\
\hline $\mathrm{V}_{1}$ & $137.10 \mathrm{a}$ & $17.17 \mathrm{a}$ & $289.00 \mathrm{a}$ & $15.83 \mathrm{a}$ & $40.92 \mathrm{a}$ & $585.00 \mathrm{a}$ \\
$\mathrm{V}_{2}$ & $116.80 \mathrm{~b}$ & $14.17 \mathrm{~b}$ & $248.10 \mathrm{~b}$ & $15.58 \mathrm{a}$ & $32.33 \mathrm{~b}$ & $554.30 \mathrm{~b}$ \\
$\mathrm{~V}_{3}$ & $98.75 \mathrm{c}$ & $10.58 \mathrm{c}$ & $190.40 \mathrm{c}$ & $15.00 \mathrm{a}$ & $30.83 \mathrm{~b}$ & $487.40 \mathrm{c}$ \\
$\mathrm{CV} \%$ & 6.83 & 17.79 & 7.68 & 13.10 & 17.09 & 3.58 \\
$\mathrm{LSD}(0.05)$ & 6.77 & 2.68 & 15.68 & 1.71 & 5.00 & 16.35 \\
\hline
\end{tabular}

In a column means similar letter (s) are statistically similar and those having dissimilar letter (s) differ significantly

\subsection{Leaf Area}

Statistically significant variation was recorded for leaf area due to seed priming treatment at 30 days after flowering. At flowering stage, the maximum leaf area $\left(332.60 \mathrm{~cm}^{2}\right)$ was recorded from $\mathrm{P}_{2}$ while the minimum leaf area $\left(158.40 \mathrm{~cm}^{2}\right)$ was found from $\mathrm{P}_{0}$ (Table 1). Seed priming treatment effects were registered on leaf area of tomato. Different varieties varied significantly on leaf area of tomato at flowering stage and 30 days after flowering. At flowering stage, the maximum leaf area $\left(289.00 \mathrm{~cm}^{2}\right)$ was obtained from $\mathrm{V}_{1}$ whereas the minimum leaf area $\left(190.40 \mathrm{~cm}^{2}\right)$ was found from $\mathrm{V}_{3}$. (Table 2).

Leaf area of tomato showed significant differences due to interaction effect of different seed priming treatment and variety at flowering stage and 30 days after flowering. At flowering stage, the maximum leaf area $\left(437.10 \mathrm{~cm}^{2}\right)$ was attained from $\mathrm{V}_{1} \mathrm{P}_{2}$ treatment combination and the minimum $\left(139.70 \mathrm{~cm}^{2}\right)$ from $\mathrm{V}_{3} \mathrm{P}_{0}$ treatment combination which was significantly similar to $\mathrm{V}_{2} \mathrm{P}_{0}\left(152.30 \mathrm{~cm}^{2}\right)$ (Table 3$)$.

\subsection{Number of Flower Cluster Per Plant}

Different seed priming treatment under salt stress significantly in terms of number of flower cluster per plant of tomato. Data revealed that the highest number of flower cluster per plant (20.44) was found from $\mathrm{P}_{2}$ while the lowest number (9.78) was recorded from $\mathrm{P}_{0}$ (Table 1).

Varieties showed no significant differences on number of flower cluster per plant of tomato. The highest number of flower cluster per plant (15.83) was recorded from $V_{1}$ which was closely followed (15.58 and 15.00$)$ by $\mathrm{V}_{2}$ and $\mathrm{V}_{3}$ respectively (Table 2 ).

Combined effect of different seed priming treatment and variety showed significant differences on number of flower cluster per plant. The highest number of flower cluster per plant (23.00) was observed from $\mathrm{V}_{1} \mathrm{P}_{2}$ treatment combination while the lowest number (9.00) was attained from $\mathrm{V}_{3} \mathrm{P}_{0}$ treatment combination (Table 3 ).

\subsection{Number of Fruits Per Plant}

Significant variation was recorded in terms of number of fruits per plant of tomato due to different seed priming treatment under salt stress. The highest number of fruits per plant (48.11) was recorded from $\mathrm{P}_{2}$ whereas the lowest number (22.22) was found from $\mathrm{P}_{0}$ (Table 1).

Number of fruits per plant of tomato showed statistically significant difference due to different varieties. The highest number of fruits per plant (40.92) was recorded from $V_{1}$ and the lowest number (30.83) was recorded from $V_{3}$ which was statistically similar to $\mathrm{V}_{2}$ (32.33) (Table 2).

Combined effect of different seed priming treatment and 
varieties observed significant differences on number of fruits per plant. The highest number of fruits per plant (55.00) was observed from $V_{1} P_{2}$ treatment combination, whereas the lowest number (16.33) was attained from $\mathrm{V}_{3} \mathrm{P}_{0}$ treatment combination which was statistically similar to (20.33) $\mathrm{V}_{2} \mathrm{P}_{0}$ (Table 3). Similarly, significant positive association of this trait with yield $[23,24]$.

\subsection{Fruit Yield Per Plant}

Different seed priming treatment varied significantly in terms of yield per plant of tomato under salt stress. The highest yield per plant $(755.80 \mathrm{~g})$ was recorded from $\mathrm{P}_{2}$ while the lowest yield $(373.10 \mathrm{~g})$ was found from $\mathrm{P}_{0}$ (Table 1$)$.

Different tomato varieties showed significant differences on yield per plant of tomato. The highest yield per plant $(585.00 \mathrm{~g})$ was recorded from $\mathrm{V}_{1}$ whereas the lowest yield (487.40 g) was observed from $\mathrm{V}_{3}$ (Table 2).

Yield per plant varied significantly due to the combined effect of different seed priming treatment and different tomato varieties under salt stress. The highest yield per plant $(523.70 \mathrm{~g})$ was recorded from $\mathrm{V}_{1} \mathrm{P}_{2}$ treatment combination and the lowest yield $(487.30 \mathrm{~g})$ was observed from $\mathrm{V}_{1} \mathrm{P}_{3}$ treatment combination (Table 3 ).

Table 3. Combined effect of different priming treatments and different varieties of tomato on plant yield contributing parameters under saline condition.

\begin{tabular}{|c|c|c|c|c|c|c|}
\hline $\begin{array}{l}\text { Treatment } \\
\text { Combination } \\
\end{array}$ & Plant height (cm) & $\begin{array}{l}\text { Number of branches } \\
\text { per plant }\end{array}$ & $\begin{array}{l}\text { Leaf area } \\
\left(\mathrm{cm}^{2}\right)\end{array}$ & $\begin{array}{l}\text { Number of flowers } \\
\text { cluster per plant }\end{array}$ & $\begin{array}{l}\text { Number of fruits } \\
\text { per plant }\end{array}$ & $\begin{array}{l}\text { Total fruit weight } \\
\text { per plant (gm) }\end{array}$ \\
\hline $\mathrm{V}_{1} \mathrm{P}_{0}$ & $83.33 \mathrm{fg}$ & $11.33 \mathrm{~cd}$ & $285.40 \mathrm{c}$ & $10.00 \mathrm{e}$ & $30.00 \mathrm{de}$ & $377.00 \mathrm{f}$ \\
\hline $\mathrm{V}_{1} \mathrm{P}_{1}$ & $141.70 \mathrm{~b}$ & $14.33 \mathrm{bcd}$ & $292.70 \mathrm{c}$ & $14.67 \mathrm{~d}$ & $41.00 \mathrm{bc}$ & $523.70 \mathrm{~d}$ \\
\hline $\mathrm{V}_{1} \mathrm{P}_{2}$ & $187.00 \mathrm{a}$ & $22.00 \mathrm{a}$ & $437.10 \mathrm{a}$ & $23.00 \mathrm{a}$ & $55.00 \mathrm{a}$ & $829.30 \mathrm{a}$ \\
\hline $\mathrm{V}_{1} \mathrm{P}_{3}$ & $136.30 \mathrm{~b}$ & $19.33 \mathrm{ab}$ & $353.10 \mathrm{~b}$ & $14.67 \mathrm{~d}$ & $37.67 \mathrm{bcd}$ & $487.30 \mathrm{e}$ \\
\hline $\mathrm{V}_{2} \mathrm{P}_{0}$ & $90.33 \mathrm{ef}$ & $8.00 \mathrm{de}$ & $152.30 \mathrm{gh}$ & $10.33 \mathrm{e}$ & $20.33 \mathrm{ef}$ & $357.00 \mathrm{f}$ \\
\hline $\mathrm{V}_{2} \mathrm{P}_{1}$ & $116.00 \mathrm{~cd}$ & $10.00 \mathrm{de}$ & 194.20 ef & $16.00 \mathrm{~cd}$ & $33.00 \mathrm{~cd}$ & $388.00 \mathrm{f}$ \\
\hline $\mathrm{V}_{2} \mathrm{P}_{3}$ & $115.30 \mathrm{~cd}$ & $15.00 \mathrm{bcd}$ & $250.30 \mathrm{~d}$ & $16.67 \mathrm{~cd}$ & $32.00 \mathrm{~cd}$ & $553.00 \mathrm{~d}$ \\
\hline $\mathrm{V}_{3} \mathrm{P}_{0}$ & $73.67 \mathrm{~g}$ & $6.67 \mathrm{e}$ & $139.70 \mathrm{~h}$ & $9.00 \mathrm{e}$ & $16.33 \mathrm{f}$ & $385.30 \mathrm{f}$ \\
\hline $\mathrm{V}_{3} \mathrm{P}_{1}$ & $100.70 \mathrm{e}$ & $16.67 \mathrm{abc}$ & 196.10 ef & $14.67 \mathrm{~d}$ & $29.33 \mathrm{de}$ & $522.30 \mathrm{~d}$ \\
\hline $\mathrm{V}_{3} \mathrm{P}_{2}$ & $118.00 \mathrm{c}$ & $11.33 \mathrm{~cd}$ & 207.60 ef & $21.33 \mathrm{ab}$ & $45.33 \mathrm{ab}$ & $786.30 \mathrm{~b}$ \\
\hline $\mathrm{V}_{3} \mathrm{P}_{3}$ & $102.70 \mathrm{de}$ & $18.67 \mathrm{ab}$ & $218.40 \mathrm{e}$ & $18.33 \mathrm{bc}$ & $32.33 \mathrm{~cd}$ & $646.00 \mathrm{c}$ \\
\hline $\mathrm{CV} \%$ & 6.83 & 17.79 & 7.68 & 13.10 & 17.09 & 25.70 \\
\hline $\operatorname{LSD}(0.05)$ & 13.53 & 5.37 & 21.37 & 3.42 & 9.99 & 3.58 \\
\hline
\end{tabular}

In a column means similar letter (s) are statistically similar and those having dissimilar letter (s) differ significantly.

\subsection{Chlorophyll and Vitamin-C Content}

Significant variation was observed for Chlorophyll content values of tomato plant due to different seed priming treatment under salt stress. At flowering stage, the highest SPAD values (47.92) was obtained from $\mathrm{P}_{2}$ whereas the lowest SPAD values (22.56) was found from $\mathrm{P}_{0}$ (Table 4)

SPAD values of tomato at flowering stage varied significantly due to different tomato varieties under salt stress. At flowering stage, the highest SPAD value (41.13) was found from $V_{1}$ which was statistically similar (39.97) with $\mathrm{V}_{2}$, while the lowest SPAD value (21.36) was recorded from $\mathrm{V}_{3}$. (Table 5).

Combined effect of different seed priming treatment and different tomato variety showed significant differences in terms of chlorophyll content of tomato at flowering stage under salt stress. At flowering stage, the highest SPAD value (51.60) was observed from $\mathrm{V}_{1} \mathrm{P}_{2}$ treatment combination and the lowest SPAD values (29.87) from $\mathrm{V}_{2} \mathrm{P}_{3}$ treatment combination. (Table 6). The results were in agreement with results reported by Hajer et al., [25], that chlorophyll content decreased with increasing water salinity and seed priming tend to protect plants from damage caused by salinity.

It was observed from the result of present experiment that different seed priming treatment significantly varied the vitamin-c in ripen tomato fruit under saline condition. The maximum Vitamin-C content $(18.06 \mathrm{mg} / 100 \mathrm{~g})$ was found from $\mathrm{P}_{2}$ while the minimum content of Vitamin-C (10.26 $\mathrm{mg} / 100 \mathrm{~g}$ ) was achieved from $\mathrm{P}_{0}$. (Table 4)
Vitamin-C content in ripen tomato varied significantly with the different tomato varieties under saline condition. The highest value of Vitamin-C content in ripen fruit was found from $V_{1}$ $(14.71 \mathrm{mg} / 100 \mathrm{~g})$ and lowest from $\mathrm{V}_{3}(9.23 \mathrm{mg} / 100 \mathrm{~g})$. (Table 5).

Combined effect of the seed priming treatment and different tomato varieties under saline condition varied significantly for the content of Vitamin- $\mathrm{C}$ of ripen tomato fruit. The maximum amount of Vitamin-C content $(24.78 \mathrm{mg} / 100 \mathrm{~g})$ was attained from $\mathrm{V}_{1} \mathrm{P}_{2}$ whereas the minimum amount of Vitamin-C content $\left(7.45 \mathrm{mg} / 100 \mathrm{~g}\right.$ ) was found from $\mathrm{V}_{3} \mathrm{P}_{0}$ (Table 6).

\subsection{Carotenoid Content}

It was noticed that from the result of the experiment, different seed priming treatment significantly varied the carotenoid in ripen tomato fruit under saline condition. The maximum carotenoid content $(5.13 \mathrm{mg} / 100 \mathrm{~g})$ was found from $\mathrm{P}_{2}$ while the minimum content of carotenoid $(2.12$ $\mathrm{mg} / 100 \mathrm{~g}$ ) was achieved from $\mathrm{P}_{0}$. (Table 4)

Significant effect of different tomato varieties observed in ripen tomato fruit under salt stress. The highest value of carotenoid content $(3.98 \mathrm{mg} / 100 \mathrm{~g})$ was found from $\mathrm{V}_{1}$ and lowest value $(2.10 \mathrm{mg} / 100 \mathrm{~g})$ was recorded from $\mathrm{V}_{3}$ (Table 5). The Combined effect between different seed priming treatment and different tomato varieties on carotenoid content of tomato plant was statistically significant. The highest carotenoid content $(5.88 \mathrm{mg} / 100 \mathrm{~g})$ was found from $\mathrm{V}_{1} \mathrm{P}_{2}$. The lowest value $(2.20 \mathrm{mg} / 100 \mathrm{~g})$ was found from $\mathrm{V}_{3} \mathrm{P}_{0}$ (Table 6 ). 
Table 4. Effect of different priming treatments on fruit quality parameters of tomato under saline condition.

\begin{tabular}{llllll}
\hline Treatments & $\begin{array}{l}\text { Chlorophyll content of } \\
\text { leaves (\%) }\end{array}$ & Vitamin-C (mg per 100gm) & Total soluble solid (brix\%) & Carotenoid (mg per 100g) & Proline (mg/g) \\
\hline $\mathrm{P}_{0}$ & $22.56 \mathrm{c}$ & $10.26 \mathrm{c}$ & $2.21 \mathrm{~d}$ & $2.12 \mathrm{c}$ & $2.11 \mathrm{~d}$ \\
$\mathrm{P}_{1}$ & $38.06 \mathrm{~b}$ & $14.13 \mathrm{~b}$ & $5.22 \mathrm{c}$ & $4.07 \mathrm{~b}$ & $3.34 \mathrm{c}$ \\
$\mathrm{P}_{2}$ & $47.92 \mathrm{a}$ & $18.06 \mathrm{a}$ & $6.82 \mathrm{a}$ & $5.13 \mathrm{a}$ & $5.45 \mathrm{a}$ \\
$\mathrm{P}_{3}$ & $40.92 \mathrm{~b}$ & $14.83 \mathrm{~b}$ & $5.94 \mathrm{~b}$ & $4.12 \mathrm{~b}$ & $3.85 \mathrm{~b}$ \\
$\mathrm{CV} \%$ & 11.98 & 5.49 & 11.28 & 8.83 & 8.55 \\
\hline
\end{tabular}

In a column means similar letter (s) are statistically similar and those having dissimilar letter (s) differ significantly.

\subsection{Proline Content}

This experiment exhibited distinct variation in proline content in leaves of tomato under salt stress at different seed priming treatment. Result on changes in proline content have been presented in (Table 4). Among the different seed priming treatment proline content was highest in $\mathrm{P}_{2}(5.45$ $\mathrm{mg} / \mathrm{g}$ ) and lowest in $\mathrm{P}_{0}(2.11 \mathrm{mg} / \mathrm{g})$ (Table 4).

Variation was noted due to the differences in different tomato varieties under salt stress. Salinity stress creates a maximum demand for proline during stress conditions in tolerant varieties to withstand against salinity stress than sensitive cultivars. The maximum proline content found in $\mathrm{V}_{1}$ $(3.87 \mathrm{mg} / \mathrm{g})$ and lowest value from $\mathrm{V}_{3}(2.09 \mathrm{mg} / \mathrm{g})$. (Table 5$)$

The Combined effect of different seed priming treatment and different tomato varieties under salt stress varied significantly on proline content in tomato leaves. Maximum proline accumulation was seen from $\mathrm{V}_{1} \mathrm{P}_{2}(6.88 \mathrm{mg} / \mathrm{g})$ under salt stress and minimum proline content found from $\mathrm{V}_{2} \mathrm{P}_{3}$ $(2.15 \mathrm{mg} / \mathrm{g})$ which was statistically similar to $\mathrm{V}_{1} \mathrm{P}_{0}(2.50$ $\mathrm{mg} / \mathrm{g}$ ) and $\mathrm{V}_{2} \mathrm{P}_{0}(2.31 \mathrm{mg} / \mathrm{g})$ (Table 6).

Table 5. Effect of different varieties on fruit quality parameters of tomato under saline condition.

\begin{tabular}{|c|c|c|c|c|c|}
\hline Treatments & Chlorophyll content of leaves (\%) & Vitamin-C (mg per 100gm) & Total soluble solid (brix\%) & Carotenoid (mg per 100g) & Proline $\mathrm{mg} / \mathrm{g}$ \\
\hline$\overline{V_{1}}$ & $41.13 \mathrm{a}$ & $14.71 \mathrm{a}$ & $4.92 \mathrm{a}$ & $3.98 \mathrm{a}$ & $3.87 \mathrm{a}$ \\
\hline$V_{2}$ & $39.97 \mathrm{a}$ & $10.58 \mathrm{~b}$ & $5.42 \mathrm{a}$ & $3.37 \mathrm{~b}$ & $3.04 \mathrm{~b}$ \\
\hline $\mathrm{V}_{3}$ & $21.36 \mathrm{~b}$ & $9.23 \mathrm{c}$ & $2.18 \mathrm{~b}$ & $2.10 \mathrm{c}$ & $2.09 \mathrm{c}$ \\
\hline CV\% & 11.44 & 5.49 & 11.28 & 8.83 & 8.55 \\
\hline $\operatorname{LSD}(0.05)$ & 3.98 & 0.67 & 0.52 & 0.29 & 0.27 \\
\hline
\end{tabular}

In a column means similar letter (s) are statistically similar and those having dissimilar letter (s) differ significantly.

\subsection{Total Soluble Solids}

Seed priming treatment had significant differences in total soluble solids under salt stress condition. Soluble sugar in ripe tomato fruit increased with $\mathrm{NaCl}$ seeds priming treatment. The data showing the changes in soluble solids content at different seed priming treatment. Maximum soluble solids found $(6.82 \%)$ when seed was treated with $50 \mathrm{mM} \mathrm{NaCl}$ and lowest value was found $(2.21 \%)$ from control $\left(\mathrm{P}_{0}\right)$. (Table 4$)$

Total soluble solid (TSS) in tomato fruit varied significantly with the different variety. It was noticed that highest TSS (4.92\%) was found from $\mathrm{V}_{1}$ which was statistically similar to $\mathrm{V}_{2}(5.42 \%)$ under saline condition and the lowest TSS $\left(1.18 \%\right.$ from $\mathrm{V}_{3}$. (Table 5)

Combined effect of different seed priming treatment and different tomato varieties varied nonsignificant on TSS of ripen tomato fruit under salt stress. It was observed that highest value of TSS $(7.80 \%)$ was found from $\mathrm{V}_{1} \mathrm{P}_{2}$ which was statistically similar to $\mathrm{V}_{1} \mathrm{P}_{3}(7.50 \%)$ while the lowest value of TSS (2.36\%) from $\mathrm{V}_{3} \mathrm{P}_{0}$ (Table 6).

Table 6. Combined effect of priming treatments and different varieties of tomato on fruit quality parameters under saline condition.

\begin{tabular}{|c|c|c|c|c|c|}
\hline $\begin{array}{l}\text { Treatment } \\
\text { Combination }\end{array}$ & $\begin{array}{l}\text { Chlorophyll content of } \\
\text { leaves }(\%)\end{array}$ & Vitamin-C (mg per 100gm) & Total soluble solid (brix \%) & Carotenoid (mg per $100 \mathrm{~g}$ ) & Proline mg/g \\
\hline $\mathrm{V}_{1} \mathrm{P}_{0}$ & $42.93 \mathrm{bcd}$ & $15.97 \mathrm{~cd}$ & $5.33 \mathrm{~d}$ & $3.65 \mathrm{e}$ & $2.50 \mathrm{f}$ \\
\hline $\mathrm{V}_{1} \mathrm{P}_{1}$ & $43.53 \mathrm{bcd}$ & $15.00 \mathrm{~d}$ & $6.67 \mathrm{bc}$ & $4.45 \mathrm{c}$ & $3.05 \mathrm{e}$ \\
\hline $\mathrm{V}_{1} \mathrm{P}_{3}$ & $46.63 \mathrm{abc}$ & $12.40 \mathrm{e}$ & $7.50 \mathrm{ab}$ & $5.24 \mathrm{~b}$ & $5.09 \mathrm{~b}$ \\
\hline $\mathrm{V}_{2} \mathrm{P}_{0}$ & 32.80 ef & $8.61 \mathrm{f}$ & $5.00 \mathrm{de}$ & $2.23 \mathrm{f}$ & $2.31 \mathrm{f}$ \\
\hline $\mathrm{V}_{2} \mathrm{P}_{1}$ & 40.37 cde & $18.58 \mathrm{~b}$ & $6.00 \mathrm{~cd}$ & 4.18 cde & $4.79 \mathrm{bc}$ \\
\hline $\mathrm{V}_{2} \mathrm{P}_{3}$ & $29.87 \mathrm{f}$ & $9.82 \mathrm{f}$ & $4.00 \mathrm{ef}$ & $1.73 \mathrm{f}$ & $2.15 \mathrm{f}$ \\
\hline $\mathrm{V}_{3} \mathrm{P}_{0}$ & $22.71 \mathrm{~g}$ & $7.45 \mathrm{~g}$ & $2.36 \mathrm{~g}$ & $1.20 \mathrm{~g}$ & $1.18 \mathrm{~g}$ \\
\hline $\mathrm{V}_{3} \mathrm{P}_{1}$ & $49.87 \mathrm{ab}$ & $17.00 \mathrm{c}$ & $3.67 \mathrm{f}$ & $4.28 \mathrm{~cd}$ & $4.38 \mathrm{c}$ \\
\hline $\mathrm{V}_{3} \mathrm{P}_{2}$ & $41.53 \mathrm{~cd}$ & $16.03 \mathrm{~cd}$ & $5.67 \mathrm{~cd}$ & $3.82 \mathrm{de}$ & $3.14 \mathrm{e}$ \\
\hline $\mathrm{V}_{3} \mathrm{P}_{3}$ & $38.63 \mathrm{de}$ & $9.92 \mathrm{f}$ & $5.00 \mathrm{de}$ & $4.37 \mathrm{~cd}$ & $4.25 \mathrm{c}$ \\
\hline $\mathrm{CV} \%$ & 11.44 & 5.49 & 11.28 & 8.83 & 8.55 \\
\hline $\operatorname{LSD}(0.05)$ & 7.96 & 1.33 & 1.05 & 0.58 & 0.54 \\
\hline
\end{tabular}

In a column means similar letter (s) are statistically similar and those having dissimilar letter (s) differ significantly. 


\section{Conclusion}

From the above-mentioned results considering, it may be concluded most of the parameters of tomato under saline condition showed positive relation with seed priming. Among the seed priming treatments, $\mathrm{NaCl}$ priming $(50 \mathrm{mM})$ showed the best result than other priming treatment. Exotic line 1 (Korean) tomato showed the highest result in growth, fruit yield and quality parameters under saline condition. Therefore, further study with more seed priming and more crop varieties may provide more conclusive and precise result.

\section{Acknowledgements}

This work was supported by CP/CPSF 3643, Higher Education Quality Enhancement Project (HEQEP), UGCB, Ministry of Education, Bangladesh.

\section{References}

[1] BBS, April, (2017). Yearbook of Agricultural Statistics-2017, $29^{\text {th }}$ Series, Page 301-302.

[2] Petersen, L. and S. Shireen. (2001). Soil and water salinity in the coastal area of Bangladesh. SRDI.

[3] Hussein M.; Nadia.; Gereadly and E. L-Desuki. (2006). Role of Puterscine in Resistance to Salinity of Pea Plants (Pisum sativum L.). Journal of Applied Science Research, 2 (9): 598604.

[4] Mass E. V. and Poss J. V. (1989). Salt sensitivity of wheat at various stages. Irrig. Sci., 10: 2940.

[5] Rana R. S. (1988). Breeding for salt resistance: concepts and strategy. Int. J. Trop. Agric., 3 (4): 236-254.

[6] Sivritepe HO, Sivritepe N, Eris A, Turhan E. (2005). The effects of $\mathrm{NaCl}$ pre-treatments on salt tolerance of melons grown under long-term salinity. Sci Hortic. 106: 568-581.

[7] Cano E. A. Boları'n M. C., Perez-Alfocea F, Caro M. (1991). Effect of $\mathrm{NaCl}$ priming on increased salt tolerance in tomato. Journal of Horticultural Science. 66. 621-628.

[8] Boları'n M. C, Perez-Alfocea F., Cano EA, Estan M. T. and Caro M. (1993). Growth, fruit yield, and ion concentration in tomato epotypes after pre- and post-emergence salt treatments. J. Am. Soc. Hort. Sci. 118: 655-660.

[9] Cayuela E., Perez-Alfocea F., Caro M., Bolarin M. C. (1996). Priming of seeds with $\mathrm{NaCl}$ induces physiological changes on tomato plants grown under salt stress. Physiol Plant. 96: 231236.

[10] Paparella, S., Araujo, S. S., Rossi, G., Wijayasinghe, M., Carbonera, D., and Balestrazzi, A. (2015). Seed priming: state of the art and new perspectives. Plant Cell Rep. 34, 12811293.

[11] Ebrahimi R., M. Ahmadizadeh, P. Rahbarian, (2014). Enhancing stand establishment of tomato cultivars under salt stress condition. South Western Journal of Horticulture, Biology and Environment. 5: 19-42.
[12] Gupta, A., M. Dadlani, M. B. Arun Kumar, M. Roy, M. Naseem, V. K. Choudhary, R. K. Maiti. (2008). Seed priming: the aftermath. Int. J. Agric Environ Biotechnol 1: 199-209.

[13] Parera C., A. and Cantliffe D. J. 1994. Pre-sowing seed priming. Hortic. Rev. 16: 109-141.

[14] Michael, A. (1978) Irrigation and Theory Practice. Vikas Pub. House Pvt. Ltd., New Delihi.

[15] Ponnamperuma, F. N. (1984). Straw as source of nutrients for wetland rice. In Organic Matter and Rice. International Rice Research Institute. Manila, Philippines. pp. 117-136.

[16] Yan M. (2015). Seed priming stimulate germination and early seedling growth of Chinese cabbage. South African journal of Botany. 99: 88-92.

[17] Farooq M., Basra SMA., Khalid M., Tabassum R., Mehmood T. 2006. Nutrient Homeostasis, Reserves Metabolism and Seedling Vigor as Affected by Seed Priming in Coarse rice, Canadian Journal of Botany, 84: 1196-1202.

[18] Neufeld H. S., Chappelka A. H., Somers G. L., Burkey K. O., Davison A. W., and Finkelstein P. L., (2006). Visible foliar injury caused by ozone alters the relationship between SPAD meter readings and chlorophyll concentrations in cutleaf coneflower. Photosynth. Res. 87: 281-286.

[19] Bates LS, Waldren RP, Teare ID (1973). Rapid determination of free proline for water stress studies. Plant and Soil. Vol. 39. pp. 205-207.

[20] Harborne, J. B. (1973). Phytochemical methods: A guide to modern techniques of plant analysis. Chapman and Hall Ltd, London.; Pp. 279.

[21] Sadavarte, K. T and Gupta, P. K. 1963. Effect of seed treatment with plant growth regulators on germination, growth and yield of brinjal. The Punjab Horticultural Journal. 2: 195199.

[22] Ismailia. 2004. Responses of tomato seeds to hydro- and osmo-priming, and possible relations of some antioxidant enzymes and endogenous polyamine fractions. Egyptian Journal of Biology. 6: 81-93.

[23] Nandapuri, K. S., Surajan, S and Terseen, L. 1973. Studies on genetic variability and correlation of some economic characters in tomato. Jounal of Research. Punjab Agricultural University. 10: 316-321.

[24] Ahmed, S. U., Sasha, H. K and Sharfudddin, A. F. M. 1988. Study of heterosis and correlation in tomato. Thai Journal of Agricultural Science. 21: 117-123.

[25] Hajer A. S.; Malibari A. A.; Al-Zahrani H. S. and Almaghrabi O. A. (2006). Responses of three tomato (Lycopersicum esculentum) cultivars to sea water salinity 1 . Effect of salinity on the seedling growth. African Journal of Biotechnology 5 (10): 855-861.

[26] Balibrea M.; Dell'Amico J.; and Bolarín C ((2000)) carbon partitioning and sucrose metabolism in tomato (Lycopersicum esculentum) plants growing under salinity. physiol plant, 110: 503. 